\title{
De- and Restabilising Schengen. The European Border Regime After the Summer of Migration*
}

\author{
Desestableciendo y reestableciendo Schengen. \\ El régimen europeo de fronteras tras el verano de migración
}

\author{
Sabine Hess \\ University of Goettingen \\ shess@uni-goettingen.de \\ Bernd Kasparek \\ bordermonitoring.eu e.V. \\ bk@bordermonitoring.eu
}

doi: http://dx.doi.org/10.18543/ced-56-2017pp47-77

Contents: I. Introduction.-II. 2011-2015. A tumbling House of Cards. 1. The Arab Spring and the breakdown of externalisation. 2. The crisis of Dublin. 3.Lampedusa and the humanitarisation of the border.-III. Challenging the border - challenging border studies paradigms.-IV. Restablisation? Dimensions of a post-2015 border regime. 1. European Agenda of Migration. Tackling the crisis before the crisis. 2. Tentative restabilisations - heightened fragmentations. 3 . Bridging the outer and the inner through the border.-V. Conclusion.

\begin{abstract}
The migrations of the year 2015 and the slow and inadequate responses of the European Union has led to a political crisis in the European Union. The institutions and policies of the European Border and Migration Regime that have evolved since the Schengen Treaties of 1985 and 1990 and the inauguration of the Common European Asylum System with the Treaty of Amsterdam (1997) were not able to formulate, let alone to implement, a timely and appropriate answer.

We argue that despite the current public perception of a "refugee crisis", the EU is indeed dealing with a deep and systemic crisis of its migration and border policies, which is rooted less in the migrations of 2015, but date back to the collapse of the Mediterranean border regime in the wake of the Arab Spring 2011 and the ensuing controversies around issues such as the perceived partiality of the refugee distribution mechanism of the Dublin system as well as the mounting public outcry given the repeated instances of tragedies in the Mediterranean, epitomised by the Mare Nostrum operation launched by the Italian state in late 2013.
\end{abstract}

* Recibido el 18 de enero de 2017, aceptado el 16 de marzo de 2017. 
Currently, we observe heterogeneous approaches to solving this crisis. Not all of them may be compatible with the Schengen system as the re-institution of national border controls is often at their core. Other suggestions involve a - at times - radical move towards a deepened europeanisation of migration and border policies, such as the creation of a European Asylum Office and a European Border and Coast Guard. Based on ethnographic research in the EU's South-East, we will discuss these developments around the ongoing dynamics of de- and restabilisation of Schengen

Keywords: Schengen, border control, migration.

Resumen: Las migraciones del año 2015 y la lenta e inadecuada respuesta por parte de la Unión Europea ha generado una grave crisis política. Las instituciones y las políticas en relación al régimen de fronteras y migraciones europeas que han evolucionado desde los tratados de Schengen de 1985 y 1990 y la inauguración del Sistema Europeo Común de Asilo con el Tratado de Amsterdam (1997) no han sido capaces de formular, y menos aún de implementar, una respuesta rápida y apropiada.

Consideramos que pese a la actual percepción de la "crisis de los refugiados”, la Unión Europea se enfrenta a una crisis más profunda y sistémica de sus políticas de migración y fronteras, enrizada no tanto en el fenómeno migratorio de 2015 sino en el colapso del régimen de frontera mediterráneo durante la primavera árabe de 2011. Esta generó una serie de controversias en torno a cuestiones como la parcialidad de los mecanismos de distribución de los refugiados del sistema de Dublín, así como la creciente indignación publica frente a las tragedias en el mediterráneo, ejemplificado por la operación Mare Nostrum lanzada por Italia a finales de 2013.

Actualmente, observamos perspectivas heterogéneas para resolver la crisis. No todas pueden ser compatibles con el sistema Schengen en la medida en que la re-institución de los controles fronterizos nacionales es parte de su fundamento. Otras perspectivas implican, en algunos casos, un cambio radical hacia una mayor europeización de las políticas de migración y fronteras, como la creación de la Oficina de Asilo Europea y la Vigilancia Europea para las Fronteras y las Costas. En base a una investigación etnográfica del sureste de la Unión Europea, analizaremos estos desarrollos en torno a las dinámicas actuales de de-y restablecimiento de Schengen.

Palabras clave: Schengen, control de fronteras, migración.

\section{Introduction}

The reality of cross-border migration in summer and autumn 2015 was overwhelming. Migrants and refugees that had mostly arrived in Greece not only demanded their right to cross towards northern and western European countries, but often pragmatically created and paved their paths across 
Europe. Their numbers were unexpected, and their strength unbelievable. They camped on the city squares all over Europe; they jumped on ferries and trains; and if the official means of transportation were blocked by the police, they literally marched hundreds of kilometers to cross the next national border. This collective yet unorganised movement which had already started in early 2015 found international attention when at the end of August 2015, thousands of refugees were blocked at the Keleti train station in Budapest and launched the "March of Hope" along the main motorway to reach Austria and Germany by foot. ${ }^{1}$ The reports of marching bodies on motorways in an attempt to cross the next intra-Schengen border and to evade police controls and European registration procedures have created iconographic images of borderland resistance. ${ }^{2}$ They stepped out of the metaphorical shadow that is mostly invoked by studies on illegal and undocumented migration and claimed political subjectivity and agency in unexpected ways. ${ }^{3}$

The advent of this new quantitative and qualitative level of migration to Europe caught the European governments by surprise. Despite indications dating back to 2013 that warned of such a rise in numbers, the European institutions did not respond in time. The European Union as a whole was embroiled in the still on-going quest to overcome the sovereign debt crisis in Europe and its economic and political repercussions. Similarly, the immediate neighbourhood of European Union had become more unstable and demanded increased political intervention on the highest levels. To this end, the years between 2011 and 2015 can be summarised as a period in which the initial dynamic of the Europeanisation of migration and border policies after 1999 had come to a certain standstill. Apart from the multiple crises demanding increased attention, the standstill was also product of the belief that the multi-layered border regime established over the previous decades - the programmes of externalisation stretching outwards,${ }^{4}$ the

${ }^{1}$ Bernd Kasparek and Marc Speer, 'Of Hope. Hungary and the Long Summer of Migration', 2015, http://bordermonitoring.eu/ungarn/2015/09/of-hope-en/; Bernd Kasparek, 'Routes, Corridors, and Spaces of Exception: Governing Migration and Europe', Near Futures Online, January 2016, http://nearfuturesonline.org/routes-corridors-and-spaces-ofexception-governing-migration-and-europe/

${ }^{2}$ See We Walk Together: A Syrian Family's Journey to the Heart of Europe. 2015. 4 January 2017. https://www.theguardian.com/world/video/2015/sep/10/we-walk-together-asyrian-familys-journey-to-the-heart-of-europe-video.

3 Sabine Hess, "Citizens on the Road": Migration, Grenze Und Die Rekonstitution von Citizenship in Europa', Zeitschrift Für Volkskunde 112, no 1 (2016): 3-183.

${ }^{4}$ Gallya Lahav and Virginie Guiraudon, 'Comparative Perspectives on Border Control: Away from the Border and Outside the State', The Wall Around the West. State Borders and Immigration Controls in North America and Europe, 2000, 55-77; Luiza Bialasiewicz, 'Off-Shoring and Out-Sourcing the Borders of EUrope: Libya and EU Border Work in the Mediterranean', Geopolitics 17, no 4 (2012): 843-66. 
rearmament of the EU external border by both technological and military means, ${ }^{5}$ the inward deployment of bordering technologies such as digital, biometric databases ${ }^{6}$ and the well-developed legal frameworks such as the Schengen Acquis, the Common European Asylum System (CEAS) including the Dublin regulation - would guarantee ample means to inhibit migratory movements towards Europe. The events of 2015 brought this complacency to a sudden end. In the course of merely one year, the political landscape around migration and border policies in Europe was not recognisable anymore, and various factions emerged, banking on different policy approaches aimed at the restabilisation of the European border regime.

It is a common denominator of border studies to emphasize the transformation of the border from a demarcation line surrounding national territory to an ubiquitous, techno-social, deterritorialised apparatus or regime producing geographically stretched borderscapes. ${ }^{7}$ This holds especially true for the European Union, which can be regarded as a "laboratory" of said transformation. ${ }^{8}$ With the Schengen agreement of 1985 , the European project had heralded the creation of a continental border regime, with the newly created notion of an 'external border' as the pivotal mechanism and space for migration control. Even despite being initially outside the formal EC/EU framework, this globally unique process of regionalisation and of supra-national harmonisation was a driving force towards an accelerated and deepened process of Europeanisation, culminating in both the Treaty of Amsterdam ${ }^{9}$ (1999)

5 Sergio Carrera and Leonhard Den Hertog, 'Whose Mare? Rule of Law Challenges in the Field of European Border Surveillance in the Mediterranean. CEPS Liberty and Security in Europe No. 79/January 2015', 2015.

${ }^{6}$ Dennis Broeders, 'The New Digital Borders of Europe EU Databases and the Surveillance of Irregular Migrants', International Sociology 22, no 1 (2007): 71-92; Vassilis S. Tsianos and Brigitta Kuster, 'Eurodac in Times of Bigness: The Power of Big Data Within the Emerging European IT Agency', Journal of Borderlands Studies 31, no 2 (2016): 235-49.

7 See inter alia Etienne Balibar, 'What Is a Border?', dans Politics and the Other Scene (London: Verso, 2002), 75-86; William Walters, 'Mapping Schengenland: Denaturalizing the Border', Environment and Planning D: Society and Space 20, no 5 (2002): 561-80; Mark Salter, 'Places Everyone! Studying the Performativity of the Border', Political Geography 30, no 2 (2011): 66-67; Noel Parker and Nick Vaughan-Williams, 'Lines in the Sand? Towards an Agenda for Critical Border Studies', Geopolitics 14, no 3 (2009): 582-87.

8 William Walters and Jens Henrik Haahr, Governing Europe: Discourse, Governmentality and European Integration (Routledge, 2004): 93; Transit Migration Forschungsgruppe, Turbulente Ränder: Neue Perspektiven Auf Migration an Den Grenzen Europas (transcript Verlag, 2007); Lahav and Guiraudon, Loc. cit.

9 Treaty of Amsterdam amending the Treaty on European Union, the Treaties establishing the European Communities and certain related acts. OJ C 340, 10.11.1997, p. 1-144. 
and later Lisbon ${ }^{10}$ (2009). ${ }^{11}$ The process resulted in the creation of an "area of freedom, security and justice" through the Treaty of Amsterdam and the parallel construction of the European border regime as "a fluid assemblage" 12 involving European Union agencies, bodies of European law, processes of standardisations and harmonisations, especially around the practices of border management, a growing military-industrialacademic complex largely funded by the EU, alongside more traditional political national apparatuses of migration control that had evolved since the 1970s and a flexible involvement of IGOs (international and intergovernmental organisations such as the UNHCR or the IOM).${ }^{13}$

If there is one central rationale at the core of the European border regime, it is driven by what Lahav and Giroudon ${ }^{14}$ have called the fundamental "control dilemma" in regard of the "twin imperatives of Schengenland", as Walters and Haahr put it. ${ }^{15}$ Pinnacled by the creation of the EU internal market, this dilemma refers to the question how to reconcile a neoliberal economic paradigm of a - preferably global - free circulation of goods, services and capital with a continued biopolitical will to control the movements of people. While the EU upholds these four freedoms internally (their inalienability is the pivotal question of the Brexit negotiations supposed to commence in spring 2017), towards the outside, the EU is merely committed to the first three of these freedoms. There is no - however abstract - commitment to a global freedom of movement for people; Rather, many authors of borders and European studies have pointed to the fact that the creation of the single market opened the door to a wide field of security actors ${ }^{16}$ and led to an intensified securitisation of questions

${ }_{10}$ Treaty on the Functioning of the European Union. OJ C 326/47, 26.10.2012, p. 455607

${ }^{11}$ Cf. Sabine Hess and Vassilis Tsianos, 'Europeanizing Transnationalism! Provincializing Europe!-Konturen Eines Neuen Grenzregimes', dans Turbulente Ränder, 2007, 24.

12 See also Bialasiewicz, Loc. cit.: 844; Walters and Haahr, Op. cit.: 105.

13 See Sabine Hess and Serhat Karakayali, 'New Governance Oder Die Imperiale Kunst Des Regierens. Asyldiskurs Und Menschenrechtsdispositiv Im Neuen EU-Migrations management', dans Turbulente Ränder (transcript, 2007); Philipp Ratfisch and Stephan Scheel, 'Migrationskontrolle Durch Flüchtlingsschutz? Die Rolle Des UNHCR Im Kontext Der Externalisierung Des EU-Migrationsregimes', dans Grenzregime: Diskurse, Praktiken, Institutionen in Europa, dir. Bernd Kasparek and Sabine Hess (Berlin: assoziation a, 2010), 89-110; Martin Geiger and Antoine Pécoud, 'The Politics of International Migration Management', dans The Politics of International Migration Management (Springer, 2010), $1-20$.

14 Loc. cit.

15 Op. cit.: 110.

16 Didier Bigo and Elspeth Guild, 'Policing in the Name of Freedom', dans Controlling Frontiers: Free Movement into and Within Europe (Ashgate: Aldershot, 2005), 1-13. 
of mobility. ${ }^{17}$ Walters and Haahr argue in this respect: "Schengenland can be seen as having certain acts of securitisation as its conditions of possibility". ${ }^{18}$

In regard of the border regime, the main practical answer to the control dilemma was, according to Lahav and Giroudon,,$^{19}$ to move border controls "away from the border and outside the states", creating multi-layered borderscapes that stretch to the outside and enact a punctuated and selective filter mechanism, akin to a "firewall" to borrow a comparison by William Walters. ${ }^{20}$ The dream, exemplified in the Commission communication on smart borders, ${ }^{21}$ was a techno-scientific vision of a "smart", invisible yet selective border that is able to distinguish between bona-fide travelers and unwanted migrants that were, labelled as "illegal migration", the main object of "border control" initiatives from the very beginning..$^{22}$

To this end, broadly speaking three paradigms were enacted within the European border regime. First, to the outside, a paradigm of "remote control" and externalisation. ${ }^{23}$ Second, a paradigm of a fortified, yet smart external border through technology, digitalisation and biometrisation. Whereas these two dimensions were extensively studied by border studies we want to point to a third one, namely an internal regime steeped in the institution of asylum and put into practice through the Dublin/Eurodac regulations,,$^{24}$ aiming at the immobilisation of migrant populations within the European territory.

17 Jef Huysmans, 'The European Union and the Securitization of Migration', JCMS: Journal of Common Market Studies 38, no 5 (2000): 751-77.

18 Op. cit.: 95.

19 Loc. cit.

20 'Border/Control', European Journal of Social Theory 9, no 2 (2006): 187-203: 197.

${ }^{21}$ Commission of the European Communities, 'Preparing the Next Steps in Border Management in the European Union', Communication from the Commission to the European Parliament, the Council, the European Economic and Social Committee and the Committee of the Regions, COM(2008) 69 final (Brussels, 13 February 2008).

${ }^{22} \mathrm{Cf}$. Commission of the European Communities, 'A Common Policy on Illegal Migration', Communication from the Commission to the Council and the European Parliament, COM(2001) 672 final (Brussels, 15 November 2001).

${ }^{23}$ Cf. Sandra Lavenex, 'EU External Governance in 'Wider Europe', Journal of European Public Policy 11, no 4 (2004): 680-700; Aristide R. Zolberg, 'Managing a World on the Move', Population and Development Review 32, no S1 (2006): 222-53; Bigo and Guild, 'Policing in the Name of Freedom'.

${ }^{24}$ Council Regulation (EC) No 343/2003 of 18 February 2003 establishing the criteria and mechanisms for determining the Member State responsible for examining an asylum application lodged in one of the Member States by a third-country national, OJ L 50/1 25.2.2003; Regulation (EU) No 603/2013 of the European Parliament and of the Council of 26 June 2013 on the establishment of 'Eurodac' for the comparison of fingerprints for the effective application of Regulation (EU) No 604/2013 establishing the criteria and mechanisms for determining the Member State responsible for examining an application for international protection lodged in one of the Member States by a third-country national or a stateless person and on requests for the comparison with Eurodac data by Member States' law 
This architecture of the European border regime broke down in summer 2015 , it collapsed confronted by a new quality of migrant arrival. In the end, it challenged not only the European Union's border and migration regime, but the EU and the European project as a whole. Against the background of our decade-long research and analysis of the dynamics of the European border regime within the collaborative research network Kritnet, ${ }^{25}$ we will however argue that the crisis of the border regime started much earlier due to both external and internal dynamics.

Methodologically, our analysis is based on an approach called "ethnographic border regime analysis", which we invented in the context of our first ethnographic research project "Transit Migration I" at the southeastern border regions of Europe (2001-2005). ${ }^{26}$ The ethnographic border regime analysis follows the practice turn in border studies. ${ }^{27}$ But, whereas most of the border studies literature and research excludes the agency of migration, the border regime approach stresses the impact of the movements of migration themselves in influencing and in fact co-producing the border regime. ${ }^{28}$ This perspective of putting migration central to the analytical

enforcement authorities and Europol for law enforcement purposes, and amending Regulation (EU) No 1077/2011 establishing a European Agency for the operational management of large-scale IT systems in the area of freedom, security and justice, OJ L 180, 29.6.2013; Liza Schuster, 'Dublin II and Eurodac: Examining the (Un)intendend(?) Consequences', Gender, Place \& Culture: A Journal of Feminist Geography 18, no 3 (2011): 401-16; Bernd Kasparek, 'Complementing Schengen: The Dublin System and the European Border and Migration Regime', dans Migration Policy and Practice, dir. Harald Bauder and Christian Matheis, Migration, Diasporas and Citizenship (Palgrave Macmillan US, 2016), 59-78.

25 Transit Migration Forschungsgruppe, Op. cit.; Sabine Hess and Bernd Kasparek, dir., Grenzregime: Diskurse, Praktiken, Institutionen in Europa (Berlin: Assoziation A, 2010); Lisa-Marie Heimeshoff et al., Grenzregime II: Migration - Kontrolle - Wissen . Transnationale Perspektiven, 1st ed. (Berlin: Assoziation A, 2014); Sabine Hess et al., dir., Grenzregime III. Der Lange Sommer Der Migration (Assoziation A, 2016); Sabine Hess et al., 'Europäisches Grenzregime. Einleitung Zur Ersten Ausgabe', Movements. Journal Für Kritische Migrations-Und Grenzregimeforschung 1, no 1 (2015).

26 Transit Migration Forschungsgruppe, Op. cit.; Migmap, 'Migmap. A Virtual Cartography of European Migration Policies', 2005. http://www.transitmigration.org/ migmap/.

${ }_{27}$ Cf. Chris Rumford, 'Theorizing Borders', European Journal of Social Theory 9, no 2 (2006): 155-69; Henk van Houtum and Ton van Naerssen, 'Bordering, Ordering and Othering', Tijdschrift Voor Economische En Sociale Geografie 93, no 2 (2002): 125-36.

${ }_{28}$ Bernd Kasparek and Sabine Hess, 'Einleitung. Perspektiven Kritischer MigrationsUnd Grenzregimeforschung', dans Grenzregime: Diskurse, Praktiken, Institutionen in Europa, dir. Sabine Hess and Bernd Kasparek (Berlin: Assoziation A, 2010), 7-22; Vassilis Tsianos and Sabine Hess, 'Ethnographische Grenzregimeanalyse', Grenzregime. Diskurse, Praktiken, Institutionen in Europa, 2010, 243-64; Vassilis Tsianos, Sabine Hess and Serhat Karakayali, 'Transnational Migration. Theory and Method of an Ethnographic Analysis of Border Regimes', Sussex Centre for Migration Research Working Paper 55 (2009). 
endeavor points to an intrinsic structural fragility of the border regime. Crisis in this respect is not reducible to a temporal anomaly or emergency situation, but has to be seen as a central structural condition. Giuseppe Sciortino underlined this connection when he characterised migration regimes as a "mix of rather implicit conceptual frames, generations of turf wars among bureaucracies, and wave after wave of 'quick fix' to emergencies $[\ldots]$ the life of a regime is a result of continuous repair work through practices". ${ }^{29}$

In this respect, under our perspective, the events of 2015 constitute less of a surprise. Rather, in our various field trips over the last years the the growing tension since 2011 and crisis ridden nature of the European border regime were always palpable. Given the internal standstill and the newly developing movements of migration, 2015 was waiting to happen. In so far the aim of this article is threefold. We start with an analysis of the developments between 2011 and 2015 leading up to the so called 'refugee crisis', or as we called it "the Summer of Migration". ${ }^{30}$ In order to do so, we follow the diverse layers and paradigms of the European border regime as sketched out above, and argue that multiple dynamics culminated in the Summer of Migration. We will discuss the implications of this analysis for border studies hinting at several conceptual shortcomings of its main, dominant paradigms. In the final section, based on recent ethnographic field work in Turkey, Greece and the Balkans as part of the research project "De- and restabilisation of the European border regime" (April-Sept. 2016), we will sketch out the different developments that can be observed as attempts of restabilisation and discuss their implications for the future of the European border regime and the European project in general.

\section{2011-2015. A tumbling House of Cards}

Since the beginning of the Arab Spring in early 2011, the parameters for a pan-European regulation of its borders have shifted quite drastically. External events accelerated by the on-going Syrian civil war and mass refugee-migration movements in the direct neighbourhood of Europe as well as internal EU and European developments, especially in the legal systems of the EU, have led to severe fragility of the border regime and have undermined several of its leading paradigms. In addition to these external and internal political dynamics, there is also a societal dynamic

${ }^{29}$ Giuseppe Sciortino, 'Between Phantoms and Necessary Evils. Some Critical Points in the Study of Irregular Migrations to Western Europe', IMIS-Beiträge 24 (2004): 17-43: 32f.

${ }^{30}$ Kasparek and Speer, Loc. cit.; Hess et al., Op. cit. 
to be addressed that led - in most western European countries - to a normalisation of the facticity of being countries of immigration whereas post-migrational cultural and societal dynamics became more mainstream. This holds especially true for Germany. After years of ardent denial of being an immigration country, Germany over the last years officially turned to a new paradigm of a proclaimed "culture of welcoming". ${ }^{31}$ In the following we will briefly scatch three main external and internal processes leading up to the developments of last year.

\section{The Arab Spring and the breakdown of externalisation}

The ongoing crisis of the European border regime cannot be understood without analysing it in a double relation with the social and democratic uprisings that started in North Africa in 2011 and that have become known as the Arab Spring. While the uprisings themselves had created a dynamic, that already in 2011 led to the collaps of the Euro-mediterranean border regime as established in the years before, their more long-term consequence was the destabilisation of the immediate neighbourhood of the European Union.

Prior to the Arab Spring, the European border regime stretching towards Africa was built heavily on the externalisation paradigm. Through diverse processes such as Barcelona Process, initiated already in 1995, or the Rabat process of 2006 and the Mediterranean Transit Migration Dialogue, dating back to 2007, many North and West African countries were to some degree involved in the European Union's migration and border management project. Its different components were usually driven by EU member states, with the backing and the support from Brussels. Beginning in the late 1990s, the Spanish government succeeded in including Morocco into its migration management project, even if events such as in Ceuta and Melilla in October 2005, when hundred of migrants that had been camped around the Spanish exclaves managed to scale the fences and enter Spanish territory, constituted bumps in the road. With the active support and financing of the newly created European border agency Frontex, Spain also managed to inhibit migratory movements towards the Canary islands, and extend the reach of the border regime to key West African countries such as Senegal and Mauretania. ${ }^{32}$

${ }^{31}$ Ulrike Hamann and Serhat Karakayali, 'Practicing Willkommenskultur: Migration and Solidarity in Germany', Intersections. East European Journal of Society and Politics 2, no 4 (2016).

32 Josefina Domínguez-Mujica, Ramón Díaz-Hernández and Juan Parreno-Castellano, 'The Canary Islands “Maritime Wall”. Migration Pressure, Security Measures and Economic 
In the central Mediterranean, the central driver Italy faced stronger obstacles than Spain. Throughout the first decade of the $21^{\text {st }}$ century, Italy had sought an agreement with Libya, in which the latter would stop the departure of migrants towards the former, and would readmit migrants from there. Under the 2008 Italian-Libyan friendship treaty, a secret protocol created the conditions for the externalisation of migration control. Soon after it entered into effect in May 2009, the different institutions of the Italian state charged with border policing commenced pushback operations in the central Mediterranean, outside Italian territorial waters. This policy was accompanied by harsh repression against vessels that would conduct rescue operations involving migrants' boats, as exemplified in the case of the Cap Anamur and the case of the Tunesian fishermen. ${ }^{33}$

Immediately after the successful initial uprising in Tunesia, the Tunesian interim government canceled the cooperation with Italy, and did not continue to inhibit migrants' vessels from departing from its coast any longer. In the following weeks and months, around 30,000 Tunisians arrived in Italy. This new quality of migration (at the time), even though it was a temporary phenomenon, already demonstrated the cracks in the architecture of the European migration and border regime. While Italy sought a special procedure to deal with this migration, the other member states insisted that the arrival of the 30,000 Tunisians had to be treated under the internal European rules of the Dublin system (see below), thus assigning sole responsibility to Italy. The Italian government, however, decided to issue Schengen visas to all Tunisian migrants who had arrived before a set date, thus granting them freedom of movement within the whole Schengen area and europeanising the issue. As an immediate reaction to the ensuing onward movement of these migrants towards France, France temporarily closed its border with Italy at Ventimiglia in April 2011. While small in scale and length, this conflict foreshadowed the conflictual processes within the EU upon the arrival of nearly a million refugees and migrants in 2015. Subsequently, the Schengen border code was reformed in 2013, granting a provision that in times of the arrival of large migrations, internal border controls could be re-instated for a certain period.

Crisis in the Mid-Atlantic', Borders, Fences and Walls: State of Insecurity, 2014, 27-50; Stephan Dünnwald, 'Remote Control? Europäisches Migrationsmanagement in Mauretanien Und Mali', Movements. Journal Für Kritische Migrations- Und Grenzregimeforschung 1, no 1 (29 May 2015); Bernd Kasparek and Fabian Wagner, 'Local Border Regimes or a Homogeneous External Border? The Case of the European Union's Border Agency Frontex', IMIS-Beiträge 40 (2012): 173-90.

${ }^{33}$ Heimeshoff et al., Op. cit.; Bialasiewicz, Loc. cit. 
With the outbreak of the Libyan civil war in February 2011 and the subsequent NATO-intervention siding with the rebellion against Qadaffi, the Italian-Libyan cooperation also ended. By the end of 2011, the externalised border regime in the Mediterranean had effectively collapsed. The number of migrants crossing the Mediterranean by boat started to rise sharply, and continued to do so over the next years, always accompanied by the spectre of shipwreck and death. Numerous attempts to re-establish the externalised border regime ended unsuccessfully. ${ }^{34}$ William Walters marks this development as particular turning point in what he describes as the "birth of the humanitarian border", as the crossing of the border became very obviously a "matter of life and death". 35

A second, now internal development, dating back to 2009, created further obstacles to the return to the previous status quo. After the commencement of the Italian pushback practice towards Libya, a group of migrants subjected to the operations sued the Italian state. Libya had not fully ratified the Geneva Refugee Convention, and many reports revealed that transit migrants were being detained in deplorable conditions in Libya. Generally, Libya could not be considered a Safe Third Country, and the Italian pushback operations were thus a violation of the Geneva Convention's non-refoulement principle. The case, which became famous as Hirsi et al. vs. Italy, ${ }^{36}$ passed through the Italian legal system and finally reached the European Court of Human Rights, which, in January 2012, found that international law was indeed applicable and that state actors were bound by it even when acting outside state territory. It thus found Italy in violation of the non-refoulement principle. While the judgement ruled on a very specific case, it had deep implications for the practices of the European migration and border regime. Effectively, it meant all manner of externalisation involving cooperation between EU member states or their institutions' cooperation with third states could be scrutinised as to their conformity with international law and the varying codifications of human rights. While not an unsurpassable obstacle to externalisation, the ECHR's verdict created a legal enclosure for such measures.

${ }^{34}$ Charles Heller and Lorenzo Pezzani, 'Ebbing and Flowing: The EU's Shifting Practices of (Non-)Assistance and Bordering in a Time of Crisis', Near Futures Online, March 2016.

35 'Foucault and Frontiers: Notes on the Birth of the Humanitarian Border', Governmentality: Current Issues and Future Challenges, 2011, 138-64: 138.

36 ECHR, Hirsi Jamaa and Others v. Italy (2012). 


\section{The crisis of Dublin}

With externalisation and remote control failing from 2011 onwards, also the EU's internal system for mobility control came under increased pressure. Complementary to externalisation, the creation of the Common European Asylum System after Amsterdam established an internal mobility regime $^{37}$ for Third-country nationals without residence permits or visas with the Dublin and the Eurodac regulations as central components.

The Dublin system, dating back to the Dublin Convention of 1990 that entered into force in 1997 and which was incoporated in the EU's legal framework in 2003, deals with the question which European state has the obligation to process an asylum application. It is explicitly not a quota system, but assigns this responsibility according to different criteria, the country of first entry being the most prominent. In practice, this of course meant that the Southern and South-Eastern EU member states situated at the EU's external border were obliged to process the majority of applications. The implementation of these rules was predicated on the Eurodac database, in which the fingerprints of all asylum seekers and irregular migrants apprehended were stored, and which allowed for the determination of the country of first entry.

Member states situated at the external border like Greece, Italy, Malta and Cyprus had begun arguing around 2008 that this mechanism was to their disadvantage and lobbied for a move towards a European quota system of some kind. These attempts, however, were largely unsuccessful. The revision of Dublin in 2013 (Dublin III) and the proposed Dublin IV regulation ${ }^{38}$ do not depart from the country of first entry rule. The political conflict around Dublin thus moved to the area of implementation. The EU member states affected most all started to move towards a lax fingerprint registration practice, thus beginning to undermine the effectiveness of the Dublin system, and making the issue of swift registration at the border a contested issue within the European border regime.

For refugees and migrants, Dublin constituted a large problem. Many of those arriving in Europe had already decided beforehand where they wanted to go, or had at least some kind of tendency. The social and transnational character of migration means as it rarely happens outside a transnational

37 Kasparek, 'Complementing Schengen'.

38 European Commission, 'Proposal for a Regulation of the European Parliament and of the Council establishing the criteria and mechanisms for determining the Member State responsible for examining an application for international protection lodged in one of the Member States by a third-country national or a stateless person (recast)', $\operatorname{COM(2016)~} 270$ final (Brussels, 4 May 2016). 
web of information and social relations which made certain places in Europe more desirable as end destinations, be it for family connections, language skills or other subjective preferences. However, once a migrant's data was registered in Eurodac, he or she was obliged to remain in the country of first entry. But many did not follow this rule and started so called "secondary movements" towards other destinations. ${ }^{39}$ This, to a certain degree started to clog the Dublin bureaucracy and also started to spill over into the national and European judiciaries as migrants, threatened with inner-European deportation, filed for protection against this administrative measure, citing the deteriorating asylum standards in the Southern EU member states as an argument for their case.

Also in this respect, in 2011 another judgement by the European Court for Human Rights, MSS vs. Belgium and Greece,,$^{40}$ marked the preliminary apogee of the breakdown of the Dublin system. Citing the virtual nonexistence of an asylum system in Greece, and the resulting appalling living conditions for asylum seekers in Greece, the court found both Greece and Belgium (which had sought to deport the plaintiff) to be guilty of human rights violations. This judgement not only effectively excluded Greece from the Dublin system, but also destroyed the fiction of a somewhat homogeneous asylum system in the European Union. In 2012, the European Court of Justice, followed suit and reinforced this consequence. More and more EU member states came under scrutiny, ${ }^{41}$ while the reform of the CEAS in 2013 did nothing to rectify this situation.

\section{Lampedusa and the humanitarisation of the border}

While the discussions on the Dublin crisis and the legal interpretations of the applicability of international law extra-territorially were largely confined to experts, the volatility of the European migration and border regime was brought into sharp focus with the tragedies that occurred in October 2013 in Lampedusa. Within the space of a few days, two shipwrecks resulted in the deaths of around 500 people. While these were not the first, nor the last, they captured the attention of the European public in an unprecedented manner. The legitimacy of hardened borders, which were clearly seen as responsible for the deaths of so many people, was

39 Giulia Borri and Elena Fontanari, 'Lampedusa in Berlin: (Im)Mobilität Innerhalb Des Europäischen Grenzregimes’, Peripherie 35, no 138-139 (2016).

40 ECHR, M.S.S. v. Belgium and Greece (2011).

41 Bernd Kasparek and Marc Speer, 'At the Nexus of Academia and Activism: Bordermonitoring.eu', Postcolonial Studies 16, no 3 (September 2013): 259-68. 
severely called into question not only by a liberal public but by prominent members of the European Commission, such as home affairs commissioner Cecilia Malmström, and the president of the Commission, José Manuel Barroso. ${ }^{42}$

However, while on the EU level there was a decisive discursive shift towards a humanitarian rational that prioritised the saving of lives at sea, in the immediate aftermath no decisive policy shift was discernible ${ }^{43}$. The Italian government's decision to initiate the Mare Nostrum operation proved to be more decisive, as, for the first time, a national government reframed its border policies, putting the saving of lives before the securing of borders ${ }^{44}$ However, the increased arrival of migrants facilitated by the rescue efforts of Mare Nostrum placed more stress on the Dublin system and registration practices in Italy slowed down severely. European pressure to replace Mare Nostrum with a mission to police the borders led to its substitution with Frontex' Operation Triton, which reprioritised secure borders over the lives of humans. This turn however was itself short-lived as another tragedy struck in April 2015. Costing nearly 800 people their lives at sea, the disaster put the humanitarian rationale squarely back on the table and underlined once more that the EU border regime needed to take a decisive step if it wanted to stay on top of developments. This was felt by the Commission, which released a portion of its upcoming "European Agenda on Migration" beforehand as the so called "Ten-Point Plan" 45 stressing the necessity to reinforce Frontex operations in the Mediterranean, urging a deployment of a navy mission (EUNAVFOR Med) against smugglers and already hinting at an improved cooperation of EU agencies.

42 Miriam Ticktin, 'The Problem with Humanitarian Borders', Publicseminar.org, 18 September 2015, http://www.publicseminar.org/2015/09/the-problem-with-humanitarianborders/; Heimeshoff et al., Op. cit.; Bernd Kasparek, 'Was War Mare Nostrum? Dokumentation Einer Debatte Um Die Italienische Marineoperation', Movements. Journal Für Kritische Migrations-Und Grenzregimeforschung 1, no 1 (2015).

${ }^{43}$ Only five days after the ship wrack the Europen Council initiated a "Task Force Mediterranean" that under the leadership of Cecilia Malmström worked on a reform program, e.g. envisioning humanitarian visa and other humanitarian, legal channels to enter into the EU. But, as a journalist collective can show this reform paper never reached the public due to strong criticisms especially by the German minister of interior Matthias Gebauer et al., 'Angekündigte Katastrophe', Spiegel, 2015, 18/2015 edition.

44 Paolo Cuttitta, 'From the Cap Anamur to Mare Nostrum. Humanitarianism and Migration Controls at the EU's Maritime Borders', dir. Claudio Matera and Amanda Taylor, CLEER Working Papers, 2014.

45 European Commission, 'Joint Foreign and Home Affairs Council: Ten Point Action Plan on Migration', Press Release, (20 April 2015), http://europa.eu/rapid/press-release_IP15-4813_en.htm 


\section{Challenging the border - challenging border studies paradigms}

In summary, the Schengen crisis unfolding between 2011 and 2015 consisted of slow and seemingly unconnected developments in the different core policy areas of the European migration and border regime. These developments posed not only challenges for the border regime and EU project in general but also for border studies' theoretical as well as methodological paradigms. Especially the dominance of the externalisation and securitisation paradigm and the epistemological disregard for the forces of migration hindered also border studies' personal to grasp the emerging crisis.

The externalisation paradigm as outlined at the beginning of the article and spelt out by border studies assumes a fundamentally unequal relationship between the European Union and Third Countries, arguing that the inclusion of the latter is a top-down process and more or less a matter of coercion, even if often in the variant of the carrot and the stick. However, the breakdown of actual externalisation as one of the fundamental components of the EU border regime reveals how there exists at the same time a reverse, dialectical condition of dependency and increased fragility on behalf of the EU. With migration ranking increasingly more prominently under the contemporary pressing political issues, the cooperation of Third countries came at an ever higher price for the EU, or was altogether unattainable due to drastic changes in the political landscape. ${ }^{46}$ Also observable is the fact that externalisation in its many forms is not a uniform policy approach, consistently fostered and pursued by European Union actors, but contingent on more or less informal deals and on personal connections that are a paramount feature of so called "informal dialogues". ${ }^{47}$ This goes a long way to explain the apparent fragility of externalisation and will need to be taken into account in further assessments, as e.g. in the EU-Turkey deal (see below).

Also the second central paradigm of border studies - its preoccupation with securitisation - casts its epistomological shadows. With its specific emphasis on actors and political fields more or less related to security and even military and its accompanying focus on restriction and illiberal actions, it has hindered to see, what we have referred to as juridification. The various judgements by European and EU courts had a decisive

46 See also Gerda Heck, Sabine Hess and Fırat Genç, 'The Multilayered Border Regime in Turkey: Contested Regionalization, Deceleration and Legal Precarization', Journal of Borderlands Studies, submitted.

47 Cf. Sabine Hess, “'We Are Facilitating States!”An Ethnographic Analysis of the ICMPD', dans The Politics of International Migration Management (Springer, 2010), 96118. 
influence on the parameters of the EU border regime. While scholars of legal anthropology like Silja Klepp ${ }^{48}$ have shown conclusively how the law of the border is often written through practice, through border work, with the stepping up of European courts, the opposite development can also be observed. The creation of a supra-national body such as the EU went hand in glove with the creation of a judiciary that in turn started to shape EU policies in a condition of what Sonja Buckel has described as "relative autonomy of the judiciary". 49

The paradigm of securitisation - more or less drawing on a hypothesis of repression - also has made it ontologically and epistemologically difficult to see a process of humanitarisation ${ }^{50}$ that we outlined above as a third dynamic from within that undermined the potential to deter. The humanitarian discourse dates back to the "White Paper" of the former British Prime Minister Blair from the year 2002, entitled „Secure Border, Safe Haven" 51 that can be designated not only as one of the founding documents for externalisation as it is mostly read; ${ }^{52}$ rather it does so by strongly appealing to a humanitarian discourse and ethics. ${ }^{53}$ It can be argued, that at that time it was merely deployed as a discursive strategy to legitimize further externalisation and an intensification of border controls. ${ }^{54}$

48 Europa Zwischen Grenzkontrolle Und Flüchtlingsschutz: Eine Ethnographie Der Seegrenze Auf Dem Mittelmeer (transcript Verlag, 2014).

49 Sonja Buckel, »Welcome to Europe«.Die Grenzen Des Europäischen Migrationsrechts (transcript, 2013).

50 We follow William Walters' Loc. cit. and Didier Fassins' 'Humanitarianism as a Politics of Life', Public Culture 19, no 3 (2007): 499 conception of humanitarianism, with which both understand more than just „,ideas and ideologies“ or ,simply the activity of certain nongovernmental actors", and rather grasp humanitarianism as a specific form of governance; as a rationality of power, thus situating the debate ,in relation to the analytics of government" Walters, Loc. cit.: 143. As Paolo Cuttitta 'Zwischen De- Und Repolitisierung. Nichstaatliche Search and Rescue-Akteure an Der EU-Mittelmeergrenze', dans Grenzregime III. Der Lange Sommer Der Migration, dir. Sabine Hess et al. (Assoziation A, 2016), 115-25. puts it, this results in a specific operational logic, which finds its expression in an ,increasingly organised and internationalised attempt to save the lives, enhance the welfare, and reduce the suffering of the world's most vulnerable populations“" Michael N. Barnett, 'Humanitarian Governance', Annual Review of Political Science 16 (2013): 379-98: 379, now also in the field of migration and flight.

51 Home Office, 'Secure Borders, Safe Haven. Integration with Diversity in Modern Britain', 2002.

${ }^{52}$ Cf. Bialasiewicz, Loc. cit.

${ }^{53}$ Cf. Sharron A. FitzGerald, 'Vulnerable Bodies, Vulnerable Borders: Extraterritoriality and Human Trafficking', Feminist Legal Studies 20, no 3 (2012): 227-44.

${ }^{54}$ Sabine Hess, 'Die Humanitäre Grenze: Zur Funktionslogik Humanitaristischer Praktiken Zwischen Stabilisierung Und Subversion/Transgression' (Graz, 2016), http:// transitmigration-2.org/wp-content/uploads/2016/09/Vortrag_Die-humanit\%C3\%A4reGrenze.pdf, Fachtagung „Dimensionen des Politischen“. 
Also in the context of our first Transit Migration research project in the early 2000s we could deduce processes that we called "NGOisation" and a "governmentalisation of politics", ${ }^{55}$ pointing to the fact that the expansion of the border regime not only functioned by means of "security"-actors, but particularly operated via the specific appeal to and articulation of humanitarian positions, as in the field of anti-trafficking policies and in the context of asylum. ${ }^{56}$ This changed under the impression of Lampedusa and became a discourse in its own right. Thereby this paradigmatic shift seemed to have been possible due to wider hegemonic changes partly also due to incessant migration struggles, transnational solidarity networks and professionalised critical knowledge practices of NGOs and legal interventions that all have more or less lead to a further juridification of the border regime and human rights based approaches over the last years.

But, most important for us, both main paradigms of border studies - that of externalisation and of securitisation - prioritize a focus on political, state like actors conceptualizing history and politics as a more or less structural mighty top-down process. In most cases, that means that migration comes into the picture - if at all - as a (also epistemological) victim of these developments, more or less as passive and "vulnerable". ${ }^{57}$ The Summer of Migration proved this as an epistemological shortcoming. It is more than necessary to add the stipulated power of migration in our very center of theory production, very obviously exhibited in the collective practices of protest and appropriation of mobility rights in 2015 .

\section{IV . Restabilisation? Dimensions of a post-2015 border regime}

It is more than just a coincidence that the Summer of Migration largely coincided with the most serious attempt at re-launching the europeanising dynamic of migration and border policies through the European Agenda on Migration. Rather, it underlines that what we have argued as the crisis of Schengen was indeed similarly perceived on the level of European institutions. In this section we will examine the policy response of the

55 Hess and Karakayali, 'New Governance Oder Die Imperiale Kunst Des Regierens. Asyldiskurs Und Menschenrechtsdispositiv Im Neuen EU-Migrationsmanagement'

56 Ibid; Miriam Ticktin, 'Sexual Violence as the Language of Border Control: Where French Feminist and Anti-Immigrant Rhetoric Meet', Signs 33, no 4 (2008): 863-89.

57 J. Olaf Kleist, 'Über Flucht Forschen. Herausforderungen Der Flüchtlingsforschung', Peripherie 35, no 138-139 (2016); see critically Sabine Hess and Serhat Karakayali, 'Fluchtlinien Der Migration. Grenzen Als Soziales Verhältnis', dans Grenzregime III. Der Lange Sommer Der Migration, dir. Sabine Hess et al. (Assoziation A, 2016); Ticktin, Loc. cit. 
Agenda, its subsequent implementations in order to tackle the perceived refugee crisis, and how these first steps translate into a post-2015 border regime.

\section{European Agenda on Migration. Tackling the crisis before the crisis}

Despite the attempts of the Barroso Commission, and specifically Home Affairs Commissioner Malmström, to effect a new initiative to realign the EU's migration policy in the light of the Lampedusa tragedies in October 2013, no palpable results could be achieved in the immediate aftermath. Only when the Juncker Commission, which assumed office in October 2014, declared migration as one of its top political priorities and created the new post of Commissioner for Migration, Home Affairs and Citizenship, taken by the former Greek defence minister, Dimitris Avramopoulos, a new dynamic around the EU's migration policy started to unfold.

In May 2015, the Commission presented its European Agenda on Migration (EAM) ${ }^{58}$ consisting of both short- and medium-term priorities. The policy objectives and measures laid down in the EAM do not represent a decisive departure from the EU's migration policies since Amsterdam and its main pillars, but rather build on them. We argue that the EAM is a policy move designed to concentrate the often disparate policy pushes of the past into one unified agenda and programme. Its purpose was to allow the Commission to regain the dynamics of the offensive, which had been lost in the previous years mainly to the Council and was supposed to give the field of migration policy a new and higher visibility in the EU. To this end, the EAM as a text is indicative of the crisis of Schengen. In the final analysis, it also highlights the absence of a gravitational centre within the larger EU border regime.

Even though the EAM is characterised by a slight shift in rationalities like describing border management as "saving lives and securing external borders" 59 -, both policy objectives and the means to achieve them remain largely unchanged. The four pillars asylum, borders, externalisation and legal migration represent the policy mix that has characterised the border and migration regime prior to the crisis, and which we have sketched out

58 European Commission, 'A European Agenda on Migration', Communication from the Commission to the European Parliament, the Council, the European Economic and Social Committee and the Committee of the Regions, $\operatorname{COM(2015)} 240$ final (Brussels, 13 May 2015).

59 Ibid: 10. 
above. Confronted with the dire condition of the asylum and externalisation pillar, an unfulfilled techno-scientific vision of a "smart border" and a 15 year long stagnation in the creation of legal avenues for migration, the Commission proposes nothing but a reinforced effort. The answer is always more EU, more centralised competencies, more harmonisation, and more funding where necessary.

This is most evident in a strategic proposal labelled as the "hotspot approach".$^{60}$ In this approach, the Commission posits the deployment of the European Asylum Support Office (EASO), Frontex, Eurojust and Europol to the literal hotspots, i.e. parts of the border perceived as especially under migratory pressure, in order to "swiftly identify, register and fingerpting incoming migrants". ${ }^{61}$ After the registration and identification, migrants are to be separated into appropriate channels. Redistribution (relocation) within the EU for some, access to the national asylum system for others, special care for those found to be vulnerable, and deportation for the rest (and possibly most).

Even though the hotspot approach first of all pledges support to the EU member states most affected by migration, it was clearly designed to address Dublin's crisis, by means of a close supervision of the procedures by EU agencies under the guise of providing expertise. The intervention of European agencies at the borders of Europe, legitimised as an emergency measure in reaction to a perceived crisis, heralds a new mode of europeanisation, as it aims at transferring central competences towards Brussels and its agencies, but confines this transfer to a scenarios of crisis and exception and does not necessarily aim at normalising this transfer. ${ }^{62}$ Genealogically, the hotspot approach draws both on the acknowledged failure of the Dublin system to enforce a uniform and consistent registration of migrants at the EU's external border, as well as on the externalised "Transit Processing Centres" as proposed in 2003 by the UK's prime minister Anthony Blair. ${ }^{63}$ While the latter were supposed to be situated outside the EU's territory, the breakdown of externalisation as described above prompted a geographical shift of the strategy towards the very border of the EU. ${ }^{64}$

60 Ibid: 6.

61 Ibid: 6.

62 Kasparek, Loc. cit.

63 'New International Approaches to Asylum Processing and Protection', October 2003.

${ }^{64}$ Melina Antonakaki, Bernd Kasparek and Georgios Maniatis, 'Counting, Channelling, and Detaining: The Hotspot Center Vial in Chios, Greece', Society \& Space, 29 November 2016. http://societyandspace.org/2016/11/29/counting-channelling-and-detaining-the-hotspotcenter-vial-in-chios-greece/; Brigitte Kuster and Vassilis S. Tsianos, Hotspot Lesbos, 2016. 


\section{Tentative restabilisations - heightened fragmentations}

Since March 2016, we are confronted across the board with multidimensional re-bordering efforts, by the EU and its agencies as well as by different factions of EU member states. They represent different rationalities and directions, with direct consequences for the respective visions for the future of the European project. These rebordering efforts have resulted in highly regionalised, ambivalent and hybrid securitarianhumanitarian regimes. Based on our research project "Transit Migration II. De- and restabilisations of the European border regime", ${ }^{65}$ where we carried out fieldwork in different countries of the Balkans, Greece and Turkey from April to September 2016, we will offer a preliminary overview of these restabilisation efforts. Even though due to the scope of this article, we will not be able to present our ethnographic material in more detail, we nevertheless deem the ethnographic approach, meaning observing dynamics in situ and in actu, indispensable for arriving at the conclusions we are presenting here.

In the wake of the Summer of Migration, all involved states along the Balkan route were quick to stage the events as an "emergency" (Calhoun 2004) and, in best humanitarian fashion, as a major humanitarian "crisis", thus legitimising a "politics of exception". ${ }^{66}$ This policy of proclaiming a "state of emergency" 67 determines the re-stabilisation of the EU border regime until today, thus making it possible to systematically undermine and lever the standards of international and European law without serious challenges to date. Indeed, in various instances we have observed carefully designed policy elements, which can be labelled as anti-litigation devices. The design of the Hungarian transit zones is a striking case. They are an elementary part of the border fence towards Serbia, and allow for the fiction that the border has not been closed for those seeking international protection, but rather that their admission numbers are merely limited due to administrative reasons: each of the two transit zones allows for 14 asylum seekers to enter Hungary every day 68,69 .

65 Transit Migration 2, 'Research Project on the de- and Restabilisations of the European Border Regime', 2016. http://transitmigration-2.org

${ }^{66}$ Didier Fassin, Humanitarian Reason: A Moral History of the Present (Univ of California Press, 2012).

67 Kasparek, Loc. cit.

${ }^{68}$ Barbara Beznec, Marc Speer and Marta Stojić Mitrović, 'Governing the Balkan Route: Macedonia, Serbia and the European Border Regime', Research Paper Series of Rosa Luxemburg Stiftung Southeast Europe (Beograd, December 2016).

${ }^{69}$ Similarly, the Commissions efforts to resume Dublin deportations to Greece until spring 2017 includes a close supervision of all Dublin returnees through the European 
Additionally, we are confronted with an authoritarian return of the national state and a very materialised version of national border controls within the larger European territory. The most concrete materialisations are the different fence construction projects, e.g. between Macedonia and Greece, at the Hungarian border with Serbia, between Slovenia and Croatia, or along the southern border of Austria. Especially in the case of Hungary, repressive legal instruments are leveraged against border crossers, with many EU member states enacting ever stricter legislation not only in the field of migration law. In many instances, this can be read as an abandonment of a humanitarian governance model of migration management encouraged through the EU over the last decades..$^{70}$ At the same time it has produced, especially along the former Balkan corridor, a hierarchical fragmentation of Europe, with different new boundaries, boffer zones and border controls that are flexibly employed by different nationstates like France to Italy; Austria to Italy; Slowenia to Croatia.

\section{Bridging the outer and the inner through the border}

Another move that is mostly pushed by the commission and the German government entails a deepened and newly accelerated europeanisation and externalisation of the border regime. It is motivated by the original spirit of Schengen - uninhibited movement within a territory strongly fenced towards the outside - and aims at keeping the European project alive and the Union together. It heavily draws on the traditional EU border regime paradigms, but couples it with the new humanitarian discourse and remixes different elements. During our fieldwork in the larger borderlands of the EU's South-East, we were able to have a first glimpse concerning its future outline.

Of course the main event structuring the current state was the entering into force of what is called the EU-Turkey deal in March 2016. ${ }^{71}$ In short, Turkey agreed to stop irregular border crossings towards the Greek Aegean islands, and to allow for the readmission of all migrants that have arrived

Asylum Support Office (EASO), thus thwarting any avenues towards repeated ECHR litigation, irrespective of the continued deplorable living conditions for refugees in Greece, which constituted the very reason why Greece dropped out of the Dublin system in 2011 European Commission, 'On the Resumption of Transfers to Greece Under Regulation (EU) No. 604/2013', Commission Recommendation (Brussels, 8 December 2016).

70 Geiger and Pécoud, 'The Politics of International Migration Management'.

71 Formally, the deal consists merely out of a common statement of members of the European Council and its Turkish counterparts. European Council, 'EU-Turkey statement, 18 March 2016', Press Release 144/16. 
on these islands after the signing of the deal due to its labeling as "safe third country of asylum". In return, the EU offered substantial financial assistance (all in all six billion Euros) to improve the situation for Syrian refugees in Turkey, as well as the resettlement to the EU of one Syrian refugee for every Syrian deported to Turkey from Greece, the so called 1:1 procedure. ${ }^{72}$

The actual implementation of the deal however has not been that straightforward. Returns to Turkey, and resettlement to the EU have been slow, as we could experience first hand in the course of our fieldwork in the Aegean in early Summer 2016. The only element that seems to be working is a sharp decline in border crossings, which may in part also be attributed to the deterring effect of being stuck on a Greek island. For, as our research project has argued, ${ }^{73}$ the deal, in conjunction with the hotspot system set up on the islands, has led to a massive respatialisation following the "excission" of the islands from the European and Greek asylum system. Also here akin to the pacific solution ${ }^{74}$ the islands are used as spatially suitable sites for a creative exclusion of migrants from rights, similar to what Alison Mountz ${ }^{75}$ has described as an "enforcement archipelago". In combination with the deal that holds all migrants on the islands, the hotspot system has been turned into a machinery for the denial of asylum. As we were told during our fieldwork in Chios, both EASO and Hellenic Asylum Services understand that it is their task to prove, in each individual case, that the person that has arrived on the island and has made an asylum application is a) inadmissible to the Greek asylum system and b) can be readmitted to Turkey.

But this systematic disenfranchisement and undermining of the right of asylum finds its continuation in Turkey due to several dynamics and contradictory legal provisions that not only burden Turkey with the task of being the watch dog for the European Union and turn it more and more into a country of unwanted and a highly precarious immigration. Additionally, as our field research has shown the effects of the deal virtually lead to a collapse of the more or less UNHCR based asylum system at Turkey leaving not only the Syrian refugees without any possibility to claim rights

72 Gerda Heck and Sabine Hess, 'European Restabilization of the Border Regime. A Report from the Contested Borders in the Aegean Region', 2016, http://transitmigration-2. org/wp-content/uploads/2016/09/txt_-European-Restabilization-Attempts.pdf

73 Antonakaki, Kasparek and Maniatis, 'Counting, Channelling, and Detaining'.

${ }^{74}$ Richard Devetak, 'In Fear of Refugees: The Politics of Border Protection in Australia', The International Journal of Human Rights 8, no 1 (2004): 101-9.

75 'The Enforcement Archipelago: Detention, Haunting, and Asylum on Islands', Political Geography 30, no 3 (2011): 118-28. 
and process their cases. Although Turkey is labeled as "first safe third country for asylum" by the EU-Turkey deal it still applies a geographical limitation to the 1951 Geneva Convention, which means it only accepts European citizens as "convention refugees". All non-Europeans have to apply to the UNHCR in order to receive the refugee status and being eligible for resettlement that in many cases endures up to six or even more years ${ }^{76}$ According to a lawyer we met, more than 250.000 recognised refugees are currently waiting in Turkey to be resettled. However, Syrian refugees are excluded from these status altogether. They have no right to seek asylum, instead they have been granted a "temporary protection status" by the Turkish government that confronts them with a highly precarious legal and social condition. ${ }^{77}$ But in 2013, UNHCR also suspended asylum applications from Afghans, citing a backlog of cases. According to our conversation partners, due to the tremendous increase of asylum seekers the UNHCR might consider to suspend the applications of all nationalities and restrict the access to the resettlement to vulnerable cases.

But on the other hand as we have been arguing in "The multi-layered border regime in Turkey", ${ }^{78}$ the deal transferred unprecedented powers to the AKP government that it is not only internationally using it silencing the critic on its increased repressions following the attempted coup etat and the emergency clause; But also domestically the deal gave the AKP government the power to use the Syrian presence as a biopolitical card to play out in the context of its internal conflicts that are heavily coded in ethnic and religious ways.

\section{Conclusion}

The dynamics of the European border regime which we have paradigmatically described in this paper remain conflicting. It is not yet possible to argue conclusively which direction the development of the European border regime, and thus the European project as a whole, will take. Nevertheless we will formulate tentative conclusions.

76 Cf. Cavidan Soykan, 'The New Draft Law on Foreigners and International Protection in Turkey', Oxford Monitor of Forced Migration 2, no 2 (2012): 38-47, http://oxmofm.com/ wp-content/uploads/2012/11/Cavidan-FINAL.pdf.

77 Feyzi Baban, Suzan Ilcan and Kim Rygiel, 'Syrian Refugees in Turkey: Pathways to Precarity, Differential Inclusion, and Negotiated Citizenship Rights', Journal of Ethnic and Migration Studies, 2016, 1-17; Zeynep Kivilcim, 'Legal Violence Against Syrian Female Refugees in Turkey', Feminist Legal Studies 24, no 2 (2016): 193-214.

${ }^{78}$ Heck, Hess and Genç, Loc. cit. 
The first concerns what we have called the gravitational centre of the European border regime. If the EAM was designed to firmly place the Commission in this centre, that particular attempt has been thwarted by the subsequent developments of the Summer of Migration. While the efforts of the Commission to maintain their various initiatives like the relocation mechanism and the hotspot approach can only be described as diligent, the initiative yet again lies with the Council these days. This has become especially evident after the summit of Bratislava in September 2016, where in the first such meeting of European heads of state or government after the Brexit-vote, a re-envisioned European Union as a security union was presented, prioritising - particularly in the field of migration and borders a re-inforced securitarian approach over a migration management approach as advocated for by the Commission over the last decade.

The second concerns fragmentation. This obviously applies to a geographical or geopolitical context. Both outside as well as inside the EU, the influence of the EU has decreased, and new regional centres of powers with divergent interests are emerging, be it the countries of the Visegrad group or post-coup Turkey. While this only implicitly touches border and migration policy, we contend that on a level of rights, the analysis of fragmentation applies as well. The discussions as to the postBrexit residence status of EU citizens in the UK, as well as the status of UK citizens in the EU underlines that the vision of a European citizenship, i.e. a homogeneous landscape of post-national rights throughout the EU has likewise failed. This is especially true for those that have from the start been excluded from EU citizenship, and who were never offered a EU equivalent to a national residence permit and a path to post-national citizenship. Most dramatic, this fragmentation of rights applies to the fringes of Europe, precisely to the Aegean islands, where a population has been systematically rendered "deportable" ${ }^{79}$ even if the actual deportations do not happen at the moment. But there, the geographical fragmentation and the fragmentation of rights coincide: The failure of externalisation is inscribed, through the hotspot approach and the EU-Turkey-deal, into the bodies and rights of the migrant population. While the bodies could not be kept external to the EU, their exteriority is re-produced in the hotspot centres, whereas deportation to Turkey under the terms of the deal serves as a deterrence.

Originally the EU-Turkey-deal was designed with a strong humanitarian dimensions in regard of the relocation scheme for Syrian refugees in line with the 1:1 procedure. In fact, what is in fact working is a strong

79 Nicholas De Genova and Nathalie Mae Peutz, dir., The Deportation Regime: Sovereignty, Space, and the Freedom of Movement (Durham, NC: Duke University Press, 2010). 
disenfranchisement effect as it produces a systematic deportability. In this regard, the EU-Turkey-deal could also be read as an EU-Greece deal: due to the deal the islands are transformed into an exceptional legal space serving as a spatialised "fence". Furthermore, the Greek government is strongly pushed to introduce an asylum system in line with EU legislation. Whereas the deal apparently empowers the Turkish government to reject criticisms by the EU, it also installs a form of a transnational governance of the "crisis" over Greece. In so far the deal has cut across the dichotomy of externalisation and internal processes and has produced a third hybrid space of a buffer zone at the fringes of Europe tying together Greece and Turkey.

\section{Bibliography}

Antonakaki, Melina, Bernd Kasparek and Georgios Maniatis. 'Counting, Channelling, and Detaining: The Hotspot Center Vial in Chios, Greece'. Society \& Space, 29 November 2016. http://societyandspace.org/2016/11/29/countingchannelling-and-detaining-the-hotspot-center-vial-in-chios-greece/

Baban, Feyzi, Suzan Ilcan and Kim Rygiel. 'Syrian Refugees in Turkey: Pathways to Precarity, Differential Inclusion, and Negotiated Citizenship Rights'. Journal of Ethnic and Migration Studies, 2016, 1-17. http://www.tandfonline.com/doi/a bs/10.1080/1369183X.2016.1192996

Balibar, Etienne. 'What Is a Border?' Dans Politics and the Other Scene, 75-86. London: Verso, 2002.

Barnett, Michael N. 'Humanitarian Governance'. Annual Review of Political Science 16 (2013), 379-98. http://www.annualreviews.org/doi/abs/10.1146/ annurev-polisci-012512-083711

Beznec, Barbara, Marc Speer and Marta Stojić Mitrović. 'Governing the Balkan Route: Macedonia, Serbia and the European Border Regime'. Research Paper Series of Rosa Luxemburg Stiftung Southeast Europe. Beograd, December 2016.

Bialasiewicz, Luiza. 'Off-Shoring and Out-Sourcing the Borders of EUrope: Libya and EU Border Work in the Mediterranean'. Geopolitics 17, no 4 (2012), 84366. http://www .tandfonline.com/doi/abs/10.1080/14650045.2012.660579

Bigo, Didier and Elspeth Guild. 'Policing in the Name of Freedom'. Dans Controlling Frontiers: Free Movement into and Within Europe, 1-13. Ashgate: Aldershot, 2005.

Blair, Anthony. 'New International Approaches to Asylum Processing and Protection', October 2003.

Borri, Giulia and Elena Fontanari. 'Lampedusa in Berlin: (Im)Mobilität Innerhalb Des Europäischen Grenzregimes'. Peripherie 35, no 138-139 (2016). http:// www.budrich-journals.de/index.php/peripherie/article/view/22409

Broeders, Dennis. 'The New Digital Borders of Europe EU Databases and the Surveillance of Irregular Migrants'. International Sociology 22, no 1 (2007), 71-92. 
Buckel, Sonja. «Welcome to Europe».Die Grenzen Des Europäischen Migrationsrechts. transcript, 2013.

Carrera, Sergio and Leonhard Den Hertog. 'Whose Mare? Rule of Law Challenges in the Field of European Border Surveillance in the Mediterranean. CEPS Liberty and Security in Europe No. 79/January 2015', 2015. http://aei.pitt. edu/60717

Commission of the European Communities. 'Preparing the Next Steps in Border Management in the European Union'. Communication from the Commission to the European Parliament, the Council, the European Economic and Social Committee and the Committee of the Regions, COM(2008) 69 final. Brussels, 13 February 2008.

- 'A Common Policy on Illegal Migration'. Communication from the Commission to the Council and the European Parliament, $\operatorname{COM(2001)~} 672$ final. Brussels, 15 November 2001.

Cuttitta, Paolo. 'Zwischen De- Und Repolitisierung. Nichstaatliche Search and Rescue-Akteure an Der EU-Mittelmeergrenze'. Dans Grenzregime III. Der Lange Sommer Der Migration. Sous la direction de Sabine Hess, Bernd Kasparek, Stefanie Kron, Mathias Rodatz, Maria Schwertl and Simon Sontowski, 115-25. Assoziation A, 2016.

- 'From the Cap Anamur to Mare Nostrum. Humanitarianism and Migration Controls at the EU's Maritime Borders'. Sous la direction de Claudio Matera and Amanda Taylor. CLEER Working Papers, 2014.

De Genova, Nicholas and Nathalie Mae Peutz, dir. The Deportation Regime: Sovereignty, Space, and the Freedom of Movement. Durham, NC: Duke University Press, 2010.

Devetak, Richard. 'In Fear of Refugees: The Politics of Border Protection in Australia'. The International Journal of Human Rights 8, no 1 (2004), 101-9. http://www.tandfonline.com/doi/full/10.1080/1364298042000212565

Domínguez-Mujica, Josefina, Ramón Díaz-Hernández and Juan Parreno-Castellano. 'The Canary Islands "Maritime Wall”. Migration Pressure, Security Measures and Economic Crisis in the Mid-Atlantic'. Borders, Fences and Walls: State of Insecurity, 2014, 27-50.

Dünnwald, Stephan. 'Remote Control? Europäisches Migrationsmanagement in Mauretanien Und Mali'. Movements. Journal Für Kritische Migrations- Und Grenzregimeforschung 1, no 1 (29 May 2015). http://movements-journal. org/issues/01.grenzregime/08.duennwald--remote-control-mali-mauretanien. html

ECHR. Hirsi Jamaa and Others v. Italy, (2012).

- M.S.S. v. Belgium and Greece, (2011).

European Commission. 'On the Resumption of Transfers to Greece Under Regulation (EU) No. 604/2013'. Commission Recommendation. Brussels, 8 December 2016.

- 'A European Agenda on Migration'. Communication from the Commission to the European Parliament, the Council, the European Economic and Social Committee and the Committee of the Regions, COM(2015) 240 final. Brussels, 13 May 2015. 
- 'Joint Foreign and Home Affairs Council: Ten Point Action Plan on Migration'. Press Release, 20 April 2015. http://europa.eu/rapid/press-release_IP-15-4813_en.htm

- 'Proposal for a Regulation of the European Parliament and of the Council establishing the criteria and mechanisms for determining the Member State responsible for examining an application for international protection lodged in one of the Member States by a third-country national or a stateless person (recast)', COM(2016) 270 final. Brussels, 4 May 2016.

European Council. 'EU-Turkey statement, 18 March 2016'. Press Release 144/16. Brussels, 18 March 2016.

Fassin, Didier. Humanitarian Reason: A Moral History of the Present. Univ of California Press, 2012.

- 'Humanitarianism as a Politics of Life'. Public Culture 19, no 3 (2007), 499. https://www.sss.ias.edu/files/pdfs/Fassin/Humanitarianism-as-politics-life.pdf

FitzGerald, Sharron A. 'Vulnerable Bodies, Vulnerable Borders: Extraterritoriality and Human Trafficking'. Feminist Legal Studies 20, no 3 (2012), 227-44. http:// link.springer.com/article/10.1007/s10691-012-9210-0

Gebauer, Matthias, Horand Knaup, Peter Müller, Maximilian Popp, Jörg Schindler and Christoph Schult. 'Angekündigte Katastrophe'. Spiegel. 2015, 18/2015 edition.

Geiger, Martin and Antoine Pécoud. 'The Politics of International Migration Management'. Dans The Politics of International Migration Management, 1-20. Springer, 2010. http://link.springer.com/chapter/10.1057/9780230294882_1

Hamann, Ulrike and Serhat Karakayali. 'Practicing Willkommenskultur: Migration and Solidarity in Germany'. Intersections. East European Journal of Society and Politics 2, no 4 (2016). http://intersections.tk.mta.hu/index.php/intersections/ article/view/296

Heck, Gerda and Sabine Hess. 'European Restabilization of the Border Regime. A Report from the Contested Borders in the Aegean Region', 2016. http:// transitmigration-2.org/wp-content/uploads/2016/09/txt_-European-RestabilizationAttempts.pdf

Heck, Gerda, Sabine Hess and Furat Genç. 'The Multilayered Border Regime in Turkey: Contested Regionalization, Deceleration and Legal Precarization'. Journal of Borderlands Studies, submitted.

Heimeshoff, Lisa-Marie, Sabine Hess, Stefanie Kron, Helen Schwenken and Miriam Trzeciak. Grenzregime II: Migration - Kontrolle - Wissen. Transnationale Perspektiven. 1st ed. Berlin: Assoziation A, 2014.

Heller, Charles and Lorenzo Pezzani. 'Ebbing and Flowing: The EU's Shifting Practices of (Non-)Assistance and Bordering in a Time of Crisis'. Near Futures Online, March 2016.

Hess, Sabine. "“Citizens on the Road": Migration, Grenze Und Die Rekonstitution von Citizenship in Europa'. Zeitschrift Für Volkskunde 112, no 1 (2016), 3-183. http://search.proquest.com/openview/b78c1346a3733e3555601c4fc8e455b5/1? pq-origsite $=$ gscholar $\& \mathrm{cbl}=9322$

- 'Die Humanitäre Grenze: Zur Funktionslogik Humanitaristischer Praktiken Zwischen Stabilisierung Und Subversion/Transgression'. Graz, 2016. http://transitmigration-2.org/wp-content/uploads/2016/09/Vortrag_Diehumanit\%C3\%A4re-Grenze.pdf. Fachtagung „Dimensionen des Politischen“. 
- “We Are Facilitating States!"An Ethnographic Analysis of the ICMPD'. Dans The Politics of International Migration Management, 96-118. Springer, 2010. http://link.springer.com/chapter/10.1057/9780230294882_5

Hess, Sabine and Serhat Karakayali. 'Fluchtlinien Der Migration. Grenzen Als Soziales Verhältnis'. Dans Grenzregime III. Der Lange Sommer Der Migration. Sous la direction de Sabine Hess, Bernd Kasparek, Stefanie Kron, Mathias Rodatz, Maria Schwertl and Simon Sontowski. Assoziation A, 2016.

- 'New Governance Oder Die Imperiale Kunst Des Regierens. Asyldiskurs Und Menschenrechtsdispositiv Im Neuen EU-Migrationsmanagement'. Dans Turbulente Ränder. transcript, 2007. http://www.academia.edu/ download/46169894/Turbulente_Rander_Hess-karakayali.pdf

Hess, Sabine and Bernd Kasparek, dir. Grenzregime: Diskurse, Praktiken, Institutionen in Europa. Berlin: Assoziation A, 2010.

Hess, Sabine and Vassilis Tsianos. 'Europeanizing Transnationalism! Provincializing Europe!-Konturen Eines Neuen Grenzregimes'. Dans Turbulente Ränder, 24, 2007. http://www.academia.edu/download/46169921/ transit_Buch_light.pdf\#page $=12$

Hess, Sabine, Bernd Kasparek, Stefanie Kron, Mathias Rodatz, Maria Schwertl and Simon Sontowski, dir. Grenzregime III. Der Lange Sommer Der Migration. Assoziation A, 2016. http://www .assoziation-a.de/dokumente/ Grenzregime\%203_Inhalt_Vorwort.pdf

Hess, Sabine, Bernd Kasparek, Maria Schwertl and Simon Sontowski. 'Europäisches Grenzregime. Einleitung Zur Ersten Ausgabe'. Movements. Journal Für Kritische Migrations-Und Grenzregimeforschung 1, no 1 (2015). http://movements-journal.org/issues/01 .grenzregime/02.einleitung.html

Home Office. 'Secure Borders, Safe Haven. Integration with Diversity in Modern Britain', 2002.

Huysmans, Jef. 'The European Union and the Securitization of Migration'. JCMS: Journal of Common Market Studies 38, no 5 (2000), 751-77. http:// onlinelibrary.wiley.com/doi/10.1111/1468-5965.00263/abstract

Kasparek, Bernd. 'Routes, Corridors, and Spaces of Exception: Governing Migration and Europe'. Near Futures Online, January 2016. http:// nearfuturesonline.org/routes-corridors-and-spaces-of-exception-governingmigration-and-europe/

- 'Complementing Schengen: The Dublin System and the European Border and Migration Regime'. Dans Migration Policy and Practice. Sous la direction de Harald Bauder and Christian Matheis, 59-78. Migration, Diasporas and Citizenship. Palgrave Macmillan US, 2016. doi:10.1057/9781137503817_4

- 'Was War Mare Nostrum? Dokumentation Einer Debatte Um Die Italienische Marineoperation'. Movements. Journal Für Kritische Migrations-Und Grenzregimeforschung 1, no 1 (2015). http://movements-journal.org/issues/01. grenzregime/11.kasparek--mare-nostrum-debatte.html

Kasparek, Bernd and Sabine Hess. 'Einleitung. Perspektiven Kritischer MigrationsUnd Grenzregimeforschung'. Dans Grenzregime: Diskurse, Praktiken, Institutionen in Europa. Sous la direction de Sabine Hess and Bernd Kasparek, 7-22. Berlin: Assoziation A, 2010. 
Kasparek, Bernd and Marc Speer. 'Of Hope. Hungary and the Long Summer of Migration', 2015. http://bordermonitoring.eu/ungarn/2015/09/of-hope-en/

- 'At the Nexus of Academia and Activism: Bordermonitoring.eu'. Postcolonial Studies 16, no 3 (September 2013), 259-68.

Kasparek, Bernd and Fabian Wagner. 'Local Border Regimes or a Homogeneous External Border? The Case of the European Union's Border Agency Frontex'. IMIS-Beiträge 40 (2012), 173-90.

Kivilcim, Zeynep. 'Legal Violence Against Syrian Female Refugees in Turkey'. Feminist Legal Studies 24, no 2 (2016), 193-214. http://link.springer.com/ article/10.1007/s10691-016-9323-y

Kleist, J. Olaf. 'Über Flucht Forschen. Herausforderungen Der Flüchtlingsforschung' . Peripherie 35, no 138-139 (2016). https://www.researchgate.net/profile/J_ Kleist/publication/283355228_Uber_Flucht_forschen_Herausforderungen_der_ Fluchtlingsforschung/links/5637437608ae88cf81bd525a.pdf

Klepp, Silja. Europa Zwischen Grenzkontrolle Und Flüchtlingsschutz: Eine Ethnographie Der Seegrenze Auf Dem Mittelmeer. transcript Verlag, 2014.

Kuster, Brigitte and Vassilis S. Tsianos. Hotspot Lesbos, 2016.

Lahav, Gallya and Virginie Guiraudon. 'Comparative Perspectives on Border Control: Away from the Border and Outside the State'. The Wall Around the West. State Borders and Immigration Controls in North America and Europe, 2000, 55-77.

Lavenex, Sandra. 'EU External Governance in 'Wider Europe', Journal of European Public Policy 11, no 4 (2004), 680-700. http://www.tandfonline.com/ doi/abs/10.1080/1350176042000248098

Migmap. 'Migmap. A Virtual Cartography of European Migration Policies', 2005. http://www.transitmigration .org/migmap/

Mountz, Alison. 'The Enforcement Archipelago: Detention, Haunting, and Asylum on Islands'. Political Geography 30, no 3 (2011), 118-28. http://www. sciencedirect.com/science/article/pii/S0962629811000096

Parker, Noel and Nick Vaughan-Williams. 'Lines in the Sand? Towards an Agenda for Critical Border Studies'. Geopolitics 14, no 3 (2009), 582-87. http://www. tandfonline.com/doi/full/10.1080/14650040903081297

Ratfisch, Philipp and Stephan Scheel. 'Migrationskontrolle Durch Flüchtlingsschutz? Die Rolle Des UNHCR Im Kontext Der Externalisierung Des EUMigrationsregimes'. Dans Grenzregime: Diskurse, Praktiken, Institutionen in Europa. Sous la direction de Bernd Kasparek and Sabine Hess, 89-110. Berlin: assoziation a, 2010.

Rumford, Chris. 'Theorizing Borders'. European Journal of Social Theory 9, no 2 (2006), 155-69.

Salter, Mark. 'Places Everyone! Studying the Performativity of the Border'. Political Geography 30, no 2 (2011), 66-67.

Schuster, Liza. 'Dublin II and Eurodac: Examining the (Un)intendend(?) Consequences'. Gender, Place \& Culture: A Journal of Feminist Geography 18, no 3 (2011), 401-16.

Sciortino, Giuseppe. 'Between Phantoms and Necessary Evils. Some Critical Points in the Study of Irregular Migrations to Western Europe'. IMIS-Beiträge 24 (2004), 17-43. 
Soykan, Cavidan. 'The New Draft Law on Foreigners and International Protection in Turkey'. Oxford Monitor of Forced Migration 2, no 2 (2012), 38-47. http:// oxmofm.com/wp-content/uploads/2012/11/Cavidan-FINAL.pdf

Ticktin, Miriam. 'The Problem with Humanitarian Borders'. Publicseminar.org, 18 September 2015. http://www.publicseminar.org/2015/09/the-problem-withhumanitarian-borders/

- 'Sexual Violence as the Language of Border Control: Where French Feminist and Anti-Immigrant Rhetoric Meet'. Signs 33, no 4 (2008), 863-89.

Transit Migration 2. 'Research Project on the de- and Restabilisations of the European Border Regime', 2016. http://transitmigration-2.org

Transit Migration Forschungsgruppe. Turbulente Ränder: Neue Perspektiven Auf Migration an Den Grenzen Europas. transcript Verlag, 2007.

Tsianos, Vassilis and Sabine Hess. 'Ethnographische Grenzregimeanalyse'. Grenzregime. Diskurse, Praktiken, Institutionen in Europa, 2010, 243-64.

Tsianos, Vassilis S. and Brigitta Kuster. 'Eurodac in Times of Bigness: The Power of Big Data Within the Emerging European IT Agency'. Journal of Borderlands Studies 31, no 2 (2016), 235-49. http://www .tandfonline.com/doi/abs/10.1080/0 8865655.2016.1174606

Tsianos, Vassilis, Sabine Hess and Serhat Karakayali. 'Transnational Migration. Theory and Method of an Ethnographic Analysis of Border Regimes'. Sussex Centre for Migration Research Working Paper 55 (2009). http://www .academia. edu/download/31178322/sussespaper.pdf

van Houtum, Henk and Ton van Naerssen. 'Bordering, Ordering and Othering'. Tijdschrift Voor Economische En Sociale Geografie 93, no 2 (2002), 125-36. http://onlinelibrary.wiley.com/doi/10.1111/1467-9663.00189/abstract

Walters, William. 'Foucault and Frontiers: Notes on the Birth of the Humanitarian Border'. Governmentality: Current Issues and Future Challenges, 2011, 13864. http://www .academia.edu/download/25286013/FoucaultandFrontiers.pdf

- 'Border/Control'. European Journal of Social Theory 9, no 2 (2006), 187-203.

- 'Mapping Schengenland: Denaturalizing the Border'. Environment and Planning D: Society and Space 20, no 5 (2002), 561-80.

Walters, William and Jens Henrik Haahr. Governing Europe: Discourse, Governmentality and European Integration. Routledge, 2004.

We Walk Together: A Syrian Family's Journey to the Heart of Europe. 2015. 4 January 2017. https:/www.theguardian.com/world/video/2015/sep/10/we-walktogether-a-syrian-familys-journey-to-the-heart-of-europe-video

Zolberg, Aristide R. 'Managing a World on the Move'. Population and Development Review 32, no S1 (2006), 222-53. http://onlinelibrary.wiley.com/ doi/10.1111/j.1728-4457.2006.tb00009.x/full

\section{Treaties and Legal Acts}

Treaty of Amsterdam amending the Treaty on European Union, the Treaties establishing the European Communities and certain related acts. OJ C 340, 10.11.1997, p. 1-144. 
Treaty on the Functioning of the European Union. OJ C 326/47, 26.10.2012, p. 455607.

Council Regulation (EC) No 343/2003 of 18 February 2003 establishing the criteria and mechanisms for determining the Member State responsible for examining an asylum application lodged in one of the Member States by a third-country national, OJ L 50/1 25.2.2003.

Regulation (EU) No 603/2013 of the European Parliament and of the Council of 26 June 2013 on the establishment of 'Eurodac' for the comparison of fingerprints for the effective application of Regulation (EU) No 604/2013 establishing the criteria and mechanisms for determining the Member State responsible for examining an application for international protection lodged in one of the Member States by a third-country national or a stateless person and on requests for the comparison with Eurodac data by Member States' law enforcement authorities and Europol for law enforcement purposes, and amending Regulation (EU) No 1077/2011 establishing a European Agency for the operational management of large-scale IT systems in the area of freedom, security and justice, OJ L 180, 29.6.2013. 


\section{Derechos de autor}

Los derechos de autor (para la distribución, comunicación pública, reproducción e inclusión en bases de datos de indexación y repositorios institucionales) de esta publicación (Cuadernos Europeos de Deusto, CED) pertenecen a la editorial Universidad de Deusto. El acceso al contenido digital de cualquier número de Cuadernos Europeos de Deusto es gratuito, transcurridos 6 meses desde su publicación. Los trabajos podrán descargarse, copiar y difundir en cualquier medio sin fines comerciales y según lo previsto por la ley; sin la previa autorización de la Editorial (Universidad de Deusto) o el autor. Así mismo, los trabajos editados en CED pueden ser publicados con posterioridad en otros medios o revistas, siempre que el autor indique con claridad y en la primera nota a pie de página que el trabajo se publicó por primera vez en $C E D$, con indicación del número, año, páginas y DOI (si procede). Cualquier otro uso de su contenido en cualquier medio o formato, ahora conocido o desarrollado en el futuro, requiere el permiso previo por escrito del titular de los derechos de autor.

\section{Copyright}

Copyright (for distribution, public communication, reproduction and inclusion in indexation databases and institutional repositories) of this publication (Cuadernos Europeos de Deusto, CED) belongs to the publisher University of Deusto. Access to the digital content of any Issue of Cuadernos Europeos de Deusto is free only six months after its publication. The content can be accessed, downloaded, copies, and distributed freely in any medium only for non-commercial purposes and in accordance with any applicable copyright legislation, without prior permission from the copyright holder (University of Deusto) or the author. Thus, the content of $C E D$ can be subsequently published in other media or journals, as long as the author clearly indicates in the first footnote that the work was published in $C E D$ for the first time, indicating the Issue number, year, pages, and DOI (if applicable). Any other use of its content in any medium or format, now known or developed in the future, requires prior written permission of the copyright holder. 